Rok XVI (2021) | 1 (31) | S. 213-224

https://doi.org/10.12797/LV.16.2021.31.16

Daria Ławrynow

Instytut Języka Polskiego Polskiej Akademii Nauk, Warszawa

daria.lawrynow@ijp.pan.pl

\title{
JĘZYKOWY I TEKSTOWY OBRAZ MAZURA NA PODSTAWIE TWÓRCZOŚCI STEFANA RUDANSKIEGO
}

Słowa klucze: Rudanski, Mazur, językowy obraz świata, tekstowy obraz świata, folklor
Keywords: Rudans'kyy, Mazur (Masovian), linguistic worldview, textual worldview, folklore

Cel niniejszego artykułu stanowi rekonstrukcja językowego i tekstowego obrazu Mazura w twórczości dziewiętnastowiecznego poety i folklorysty Stefana Rudanskiego na tle porównawczym materiału folklorystycznego dawnej Rusi Halickiej i Podola. Wybór źródeł folklorystycznych jest motywowany rolą tzw. ludowego obrazu świata w kształtowaniu twórczości Rudanskiego. W założeniach metodologicznych została przyjęta definicja językowego obrazu świata (JOS) opracowana przez Jerzego Bartmińskiego (1999: 110, 2010), a także przez Jolantę Maćkiewicz (1999: 11-12). Definicja ta zakłada, iż język jest nośnikiem określonej interpretacji rzeczywistości, swoistym zapisem doświadczeń i poglądów mówiącego (Bartmiński 1999: 110, 2000; Maćkiewicz 1999: 11-12). Ów termin zazwyczaj bywa odnoszony do określonej zbiorowości mówiących, np. grupy etnicznej czy zawodowej. Stąd w badaniach często pojawia się dodatkowe rozróżnienie innych „obrazów świata” w ramach JOS, np. ideologicznego czy tekstowego (por. np. Żuk 2010: 239-257; Pielużek 2015: 795-828; Tokarski 2016: 28-37). Tematyka niniejszego artykułu również wymaga doprecyzowania użytych pojęć. Wychodząc od przyjętych wyżej definicji, można przyjąć, iż tekstowy obraz świata (TOS) będzie rozumiany jako autorska interpretacja zjawisk, czerpiąca jednakże z JOS. Według koncepcji Wojciecha Kajtocha tekstowy obraz świata „jest swoistą dokonaną w konkretnym tekście - lub w zespole tekstów - realizacją językowego obrazu świata” i „[...] wskazuje na dominujący w danym tekście (zespole 
tekstów) pogląd na temat istnienia i funkcjonowania poszczególnych składników świata" (Kajtoch 2008: 14-15), może być też źródłem indywidualnej transformacji utrwalonych konwencji (Borowska 2005: 97-98). Zdaniem Bartmińskiego JOS już sam w sobie stanowi określony punkt widzenia mówiącego - odzwierciedlony w języku bądź utrwalony w tekście (Bartmiński 1999: 110-118). Ów badacz wprowadził dodatkowe pojęcie „ramy doświadczeniowej” podmiotu mówiącego, na którą składa się zarówno to, co „kulturalnie utrwalone”, „zrytualizowane”, jak i indywidualne doświadczenie nadawcy (Bartmiński, Niebrzegowska 1998: 213).

Owo wzajemne dopełnianie się JOS i TOS, semantyczna aktualizacja - mają miejsce w twórczości Stefana Rudanskiego.

Postać Mazura stanowiła dla społeczności ukraińskiej czy białoruskiej element ludowego konceptu „obcego”, przybysza z zewnątrz, utożsamiającego cechy „dzikości”, czegoś nieznanego i nie do końca oswojonego. W polskiej kulturze osoba Mazura znamionowała „swojego obcego" - nieokrzesanego, wyśmiewanego, znajdującego się niejako na marginesie życia kulturalnego Rzeczypospolitej, choć będącego jego integralną częścią.

Jak wynika z ustaleń Jeleny L. Berezowicz i Walerii S. Kuczko, języki ukraiński i białoruski, a za ich pośrednictwem również język rosyjski, przejęły negatywnie nacechowany leksem Mazur z języka polskiego jako apelatyw (Berezovich, Kuchko 2017: 413-448). Studia folklorystyczne i polskie teksty również potwierdzają ów negatywny obraz i takież konotacje (por. Smoleński 1908: 43-68, 136-147; Bystroń 1995: 131-151, tam też stosowne odnośniki do tekstów źródłowych). Szczególny obiekt kpin stanowił sposób mówienia szlachty mazowieckiej, często hiperbolizowany w tekstach prześmiewczych (Dobrzycki 1900: 15-16; Bystroń 1995: 131-151).

W językach wschodniosłowiańskich określenia Mazur i pochodne Mazurik miały dodatkowo takie znaczenia jak 'złodziejaszek, oszust, chuligan', a także 'niechluj' (Berezovich, Kuchko 2017: 417-419, 428, 430).

Sama nazwa Mazowsze w polskiej tradycji badawczej była wiązana bądź to z gniazdem semantycznym leksemów maź, mazać, bądź też z nazwą topograficzną lub dzierżawczą (Kieffer-Kostanecka 1969: 23-24; Gieysztor, Samsonowicz 1994: 86-87; Malec 2002: 156-157).

Co ciekawe, wśród niektórych polskich pisarzy, nie zawsze przychylnych buntom i rozbojom kozackim, zdarzało się przypisywanie mazowieckiego pochodzenia ich przywódcom ${ }^{1}$.

1 Dla przykładu przywódca pierwszego powstania kozackiego Krzysztof Kosiński nazywany jest przez Aleksandra Jabłonowskiego „Mazurem [...], szlachciciem podlaskim” (1910: 47). Według 
Leksemy Kozak i Mazur mogły również niekiedy funkcjonować jako symbole określonego stylu życia: swobodnego, rozbójniczego i hulaszczego. Z taką sytuacją mamy do czynienia np. w niektórych wariantach pieśni kozackich (por. Kireyevskiy 1864: 23, 25-28, 30-32; Putilov, Dobrovol'skiy 1960: 507)².

Folklorystyczne postaci Mazuriszki/Muzuryszki były też utożsamiane z tureckimi lub perskimi murzami - najprawdopodobniej stanowiąc tym samym językową reprezentację "obcego"

W ludowych anegdotach Galicji i Podola, będących źródłem lokalnych stereotypów językowych i etnicznych, Mazura charakteryzują cechy takie, jak powierzchowna pobożność i kombinatorstwo, słaba znajomość obrzędowości i zasad własnej (katolickiej) religii, prostota, a niekiedy wręcz prostactwo (Hnatyuk 1899: 175, 177-184), ale również spryt, pijaństwo, impulsywny charakter (Vremennik': 128; Chubinskiy 1878: 580; Hnatyuk 1904: 136-137; Ioanidi, Bondarenko 1984). W materiale ukraińskim i białoruskim spotykamy również prześmiewczy obraz „mądrego Mazura”: nieokrzesanego, nieudolnego oszusta (Nomys 1864: 61, 246, 269; Radzik 1997; Franko 2010: 162-166; Berezovich, Kuchko 2017: 422-424, 426).

Obcość kulturową Mazurów w folklorze Galicji i Podola podkreślał ich język stylizowany na polską gwarę ludową. Repliki niekiedy były zapisywane alfabetem łacińskim - w konfrontacji do całości utworów, zapisanych cyrylicą, np. [...] Had'ïxas Русин і того найшов. А він єго здибає тай: Cłowjycy, niy znalaz ty worecyk, a w worecku torbecky [...] (Hnatyuk 1899: 175, por. też ibid.: 177-184, Hnatyuk 1904: 136-137). Powtarza się tu zapis mazurzenia - c zamiast $c z$ - oraz kresowego zwężenia samogłoski $e$ w $y$ : cłowjycy 'człowiecze', worecyk 'woreczek', torbecky 'torbeczki'.

Carla Goehringa „Chmielnicki nie miał właściwie żadnej ojczyzny”, gdyż jego ojciec miał być banitą - szlachciciem z Mazowsza (Goehring 1867: 160), podobną wzmiankę znajdujemy u Józefa Szujskiego (1864: 305). Felicjan Kozłowski wspomina natomiast o rzekomym piętnastowiecznym przywódcy kozackim „Płocczaninie Wawrzeńcu Kozłowskim” (1858: 443).

2 Na przykład w jednej z pieśni o Jermaku: „Выплывалы - выгребали добры молодцы, славные мазурушки" (Kireyevskiy 1864: 26). Analogicznie w polskim piśmiennictwie przełomu XIXXX w. Kozaczyzna bywała symbolem społeczności niezależnej, autonomicznej. Wprowadzenie do tekstów porównań do Kozaków było ówczesnym zabiegiem służącym oddaniu specyfiki regionalnych różnic niektórych polskich grup ludności, np. Aleksander Połujański nazywał społeczność Kurpiów „takim prawie z pochodzenia narodem, jakim byli Kozacy na Zaporożu” (1859: 46-47), Tadeusz Wojciechowski porównywał Mazowsze do Zaporoża, gdyż „[...] miało dla Polski takie znaczenie, jak późniejsza kozaczyzna [...], była to ukraina graniczna [...] którą trzeba było strzedz” (1873: 270), a Michał Bobrzyński nazywał Mazowszan „,rodzajem najdawniejszej Kozaczyzny polskiej" (1879: 61).

3 Stąd zapewne przesunięcie semantyczne czasownika kozaczyć się i rzeczownika Kozaczka w dialektach polskich - tu oznaczających złe prowadzenie się, grzeszne życie młodej dziewczyny (por. np. Kolberg 1963: 21; Pajdzińska 2001: 42; Niewiara 2010: 174). Por. również rolę Kozaka i Mazura jako obcego przybysza, niosącego niebezpieczeństwo w polskim, ukraińskim oraz białoruskim folklorze weselnym i w niektórych pieśniach „życia codziennego” (tzw. pieśni bytowe) (Andrusieczko 1999: 369-377; Novak 2011: 19, 56, 61, 99, 124, 151). 
Mazurzy w przykładach folkloru ukraińskiego mówią swoistą mieszanką ukraińsko-polską, jednak nie stanowi ona odzwierciedlenia ich faktycznej gwary kresowej. Jest za to wynikiem zabiegów stylistycznych, których celem było ukazanie „swojego obcego". Tym samym w utworach zapis formy zmazurzonej sąsiaduje np. z literacką polską ortografią (samogłoski nosowe $a$ i $e$ ) czy z kresowymi cechami wymowy (zwężenie nieakcentowanej samogłoski $e, o$ ), a mazurzeniu podlega nawet ukraińskie słownictwo, zapisane cyrylicą, np. Всистки, Бозиз, зінка (Vremennik': 128; Hnatyuk 1899: 175, 177-184) ${ }^{4}$. Może to sprawiać wrażenie pewnej sztuczności, nienaturalności językowej, lecz ów zabieg służył zapewne wprowadzeniu dodatkowego komizmu i uwypukleniu „inności” bohatera.

W ukraińskiej twórczości ludowej Mazur również odróżnia się językowo od Polaka - „pana”. Ten ostatni jest przedstawicielem warstw wyższych, wykształconych, zatem jego repliki są zbudowane w oparciu o literacką polszczyznę (Hnatyuk 1899: 174-176, 184).

W kontekście języka polskiego leksem Mazur odnosił się do mieszkańców Mazowsza oraz - rzadziej - do niektórych mieszkańców Małopolski okolic dawnej Puszczy Sandomierskiej, a później również do polskich mieszkańców Warmii i Mazur (SWil I: 640; SW II: 907).

W przypadku obszarów zdominowanych przez wschodniosłowiańską ludność prawosławną i greckokatolicką (Podlasie, dzisiejsza Ukraina i Białoruś, Kazachstan) nazwa Mazur odsyłała natomiast do denotatów odwołujących się do wyznania (katolicyzm) i nieszlacheckiego pochodzenia miejscowych „Mazurów”, a także ich „chłopskiego”, „niepoprawnego” języka polskiego (Dzięgiel 2013: 118-119) ${ }^{5}$. Miała zatem charakter apelatywny, a niekiedy również przezwiskowy, a nie etnonimiczny.

Sam podział na „Mazurów” (polskich chłopów) i „Lachów” (polską szlachtę) był żywotny w świadomości zarówno Ukraińców, jak i Polaków pielęgnujących podziały stanowe. Obie wymienione grupy zasiedlały oddzielne wsie lub części wsi, podtrzymywały endogamię, mówiły różnymi odmianami języka polskiego (ibid.: $117-119)^{6}$. Mazurzy na terenie Galicji byli też często utożsamiani przez Rusinów z polskimi chłopami kolonizatorami, przesiedlonymi na Ruś z Małopolski - w związku

4 Wprowadzenie mazurzenia było popularnym w kulturze polskiej i ukraińskiej zabiegiem stylistycznym, charakteryzującym osobę Mazura (por. np. w dramatach szkolnych, intermediach XVII-XVIII w., szopkach i wertepach). Komiczna postać Mazura symbolizowała tam prostaka, skłonnego do zwady i hulanki (por. Wolanowski 1896: 479-480; Lewin 1961: 20-21; Kadulska 1982: 15-18, 22-24; Okoń 1986: 116; Kurochkin 2011: 104).

5 Co ciekawe, jak pisze Anna Tyrpa, polskojęzyczni mieszkańcy wsi okolic Białej Podlaskiej samych siebie nazywają Mazurami, natomiast wszystkich miejscowych Ukraińców - Kozakami (2006: 183-184).

6 Współczesne badania potwierdzają wciąż żywą świadomość dawnego podziału stanowego, wynika to np. z wypowiedzi i wspomnień respondentów z badanych wsi „chłopskich” i „szlachec-

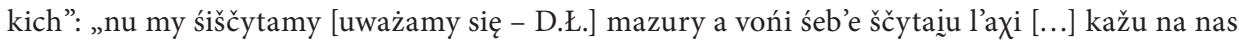
i mužyk'i [...] vońiśi mało žènil'i kažu z mazurami”" (Dzięgiel 2010: 205). 
z uczestnictwem w rabacji galicyjskiej w 1846 r. (zwanej ówcześnie „rzezią mazurską”, gdyż brali w niej liczny udział małopolscy chłopi, tzw. „Mazurzy”, por. Franko 2010: 163-166). Tymczasem leksem Lach w środowisku kresowym odnosił się do pana - przedstawiciela wyższych warstw społecznych, na ogół szlachcica bądź magnata, dysponującego znacznie większymi przywilejami aniżeli rdzenny mieszkaniec Rusi (Silets'kyy 2009: 123-130). Obie nazwy, Mazur i Lach, ulegały pejoratywizacji (Dzięgiel 2013). O deprecjonującym charakterze nazwy Lach świadczą również przykłady językowe folkloru kozackiego, gdzie owym mianem wtórnie określano wszelkiego rodzaju „zdrajców” - czyli także tych przedstawicieli ukraińskiego narodu, którzy nie przyłączyli się do antypolskich siedemnastowiecznych powstań kozackich (Myshanych 2003: 408-409; Semenoh 2004: 103).

Jak zatem widzimy, czas i przestrzeń, które ukształtowały Stefana Rudanskiego, stanowiły obszar zetknięcia różnych archetypów ludowych i stereotypów językowych. Nie bez znaczenia był też skład etniczny jego rodzinnych ziem. Rudanski urodził się we wsi Chomutyńce (Chomutynci) dzisiejszego obwodu winnickiego w 1834 r. (w 1833 r. według starego stylu) (Kryms'kyy, Levchenko 1926: 1-2). Wśród mieszkańców rodzinnych stron autora przeważali Ukraińcy, prócz nich okolice zamieszkiwali Polacy (katolicy) oraz Żydzi (Herasymenko 1925: 20). Jak wynika z ustaleń dziewiętnastowiecznego etnografa i językoznawcy Kościa Michalczuka, ogólny procent ludności rzymskokatolickiej w obwodzie winnnickim wynosił wtedy 10,53 (Michalczuk, Czubiński 2006: 230), natomiast liczba samych Mazurów (również zaliczanych do katolików, ale wymienionych przez Michalczuka oddzielnie) to: 204 mężczyzn i 185 kobiet (ibid.: 250). Według Słownika geograficznego Królestwa Polskiego powiat winnicki liczył 8,9\% ludności rzymskokatolickiej, Polacy stanowili drugą (po „Małorusach”) co do wielkości grupę mieszkańców (SGKP: 558).

Rudanski pochodził z rodziny duchowieństwa greckokatolickiego, której nieobce były polskie wpływy kulturalne (Otamanovs'kyy 1929: 119-123). Znajomość polskiej literatury i języka wywarła wpływ na wczesną twórczość poety (Kryms'kyy, Levchenko 1926: 7-10, 167-168, 203).

$\mathrm{Na}$ rozwój artystyczny autora wpłynęła też atmosfera środowiska rodzinnego: ojciec Rudanskiego odnosił się z pewną pogardą do wszystkiego, co uważał za zbyt „chłopskie”, m.in. do twórczości ludowej, ale również do języka ukraińskiego, preferując - jako „lepsze” - języki rosyjski i polski (Otamanovs'kyy 1929: 122-123; Piddubna 2014: 162). Nie bez znaczenia dla kształtowania się profilu artystycznego autora były też ówczesne tendencje społeczno-kulturalne: „kozakomania”, „chłopomania”, „bałagulstwo” (Zems'kyy 2015: 396-397) - dla których inspirację stanowiły kultura chłopska i folklor ukraiński.

Twórczość Rudanskiego koncentrowała się wokół typów etnicznych znanych mu zarówno z historii, jak i z życia codziennego. Stąd głównymi bohaterami jego dzieł byli: Kozacy, Rusini, polska szlachta, podolscy „Mazurzy”, Żydzi, „Moskale” i duchowieństwo. Dominującą formę twórczości stanowiły inspirowane folklorem 
wiersze i satyry, ballady, poematy o tematyce historycznej. Rudanski stworzył też autorski gatunek literacki - „spiwomowkę". Były to wierszowane, humorystyczne utwory, inspirowane ukraińskim folklorem (Yermolenko 2009: 16; Kosmeda 2016: 55-56). Ich tematyka niemal zawsze nawiązywała do realiów „małej” i „wielkiej” ojczyzny autora: Podola i Ukrainy.

Lokalne realia w twórczości Rudanskiego zostały oddane poprzez wprowadzenie elementów wielojęzyczności i w postaci stylizowanych dialogów. Bohaterowie mówią językiem znanym autorowi z życia codziennego. Zwracają jednak uwagę pewne błędy w ortografii (np. łżesż albo vody zamiast wody (Kryms'kyy, Levchenko 1926: 10, 49-50; Herasymenko 1956: 4-6, 22; Kosmeda 2015).

Stąd rodzi się pytanie: czy ów fakt świadczy o pomyłce drukarskiej, niedostatecznej znajomości zasad polskiej pisowni czy może jedynie stylizacji na polską gwarę?

Same „spiwomowki” stanowią przykład swoistej intertekstualności - autorskiego „dialogu” z twórczością ludową i jednocześnie jej interpretacji (Yermolenko 2009: 16-18; Piddubna 2014: 162). Mamy tym samym do czynienia $z$ wielogłosem: „mówią” zarówno przedstawiciele różnych kręgów kulturowo-językowych, jak i autor, który prowadzi swego rodzaju grę językową, żonglując różnymi językami i kontekstami ich użycia.

Charakterystykę, swoisty portret bohaterów poznajemy poprzez opis ich działania, a także poprzez ich wypowiedzi. Monologi Mazura wskazują na skłonność bohatera do refleksji, chęć wyrażania własnej opinii, a także na prostoduszność, która wraz ze szczerością replik tworzy obraz komiczny.

Wypowiedzi Mazura zawierają cechy języka mówionego, takie jak np. porzekadła: Хто із блазнями зайде, Той сам блазнем буде (Kto z błaznami przestaje, sam się błaznem staje) (Rudans'kyy 1988: 186).

Dla jego wypowiedzi charakterystyczne są polonizmy lub całe wyrażenia po polsku, które w przeciwieństwie do reszty tekstu zostały zapisane alfabetem łacińskim, np. [...] O, завсігди, пане!, - „Ksiądz ma dzieci, i ten chrzci?” // - „А що ж тутай злого?"і daleј [...] Коли так, - промовив, - Јеzи, // Ти судити нас будеш [...] (ibid.: 175, 179). Ma to dodatkowo podkreślić odrębność etniczną bohatera.

Rudanski skupia się na ukazaniu postępowania bohatera, natomiast przymiotniki odnoszące się do jego charakterystyki zewnętrznej stanowią rzadkość.

Główną cechą Mazura, wyeksponowaną w omawianych utworach, jest powierzchowna, swoiście pojęta „nabożność”. W utworze pt. Mazur na spowiedzi mamy zatem osobliwy dialog w konfesjonale młodego księdza i starego Mazura. Ten ostatni reprezentuje swoisty światopogląd „na opak” - przeciwstawny tradycyjnym poglądom religijnym: wyznaje, iż nie uczynił nic złego, gdyż unikał kościoła, natomiast regularnie odwiedzał karczmę. Dodatkowym uzasadnieniem jego „bezgrzeszności” ma być stwierdzenie: Слава богу, господь крив (Dzięki Bogu, Pan jednooki) (ibid.: 185-186). Prostoduszny Mazur uznaje zatem na podstawie tradycyjnego wyobrażenia Boga jako Oka Opatrzności, iż ten nie jest w stanie zobaczyć wszystkich uczynków, 
a tym samym nie stanowią one grzechów. Za pomocą owej w zamyśle komicznej repliki autor ukazuje takie cechy charakteru bohatera, jak prostoduszność, naiwność, przyziemność, szczerość, skłonność do pijaństwa (poprzez wskazanie na częste wizyty w karczmie). W dalszej części utworu zostaje ukazana emocjonalna reakcja młodego księdza, który nazywa Mazura grzesznikiem i pyta go, czy przypadkiem nie ma dziecka na boku. Odpowiedź może wskazywać zarówno na wspomnianą wcześniej prostoduszną szczerość, jak i na pobłażliwy stosunek starszego człowieka do młodszego spowiednika: Chciał nawet, ale gdzie-ż tam! Nie te lata, co u ciebie, synku! (ibid.). Mamy zatem przeciwstawienie kategorii starego i młodego wraz z implikacją tego, co „wypada” i „jest możliwe” dla danej kategorii wiekowej.

Kumulacja emocji następuje na końcu utworu: zostaje opisana reakcja księdza, który w przypływie gniewu szarpie Mazura za włosy, a także słowna reakcja „ofiary”. Mazur nie ucieka się do przemocy, lecz jedynie komentuje całą sytuację stwierdzeniem, iż Хто із блазнями зайде, Той сам блазнем буде (ibid.). Może to wskazywać na przekonanie o słuszności własnej postawy. Utwór zestawia ze sobą dwie postawy etyczne, a efekt komiczny wynika $\mathrm{z}$ odmiennej konceptualizacji dobrego i złego uczynku.

Temat swoiście pojętej pobożności i wiary w komicznym ujęciu spotykamy również w utworze pt. Mazur w bagnie. Opisane w nim zostały próby wydostania się z bagna, w którym wraz z wozem utknął bohater. Zwraca się on o pomoc do świętych: najpierw do Doroty, a następnie do Antoniego. Pierwsza modlitwa nie przynosi skutku, natomiast przy drugiej konie ruszają wraz z wozem - jak sugeruje autor, było to spowodowane „krzykiem” Mazura (ibid.: 186-187). Ten ostatni odczytuje sytuację w kategoriach cudu uczynionego za sprawą świętego. Następujący komentarz Mazura odzwierciedla patriarchalny - stereotypowy - sposób myślenia: Om w̧o хлопещь! Не то, щзо Дорота (Ot, со znaczy chłopiec! Nie to, co Dorota!) (ibid.: 187). Również w tym utworze mamy „mieszany” zapis tekstu: Давай moдi Antoniego Напоміч проситu, następnie Swięty мій Антоніŭ! Męski święty jest tutaj „łaciński” - w przeciwieństwie do „ruskiej” w zapisie Doroty.

Kolejny prześmiewczy przykład „swoistego życia religijnego” daje nam utwór pt. Kamienny święty. Mamy tu opis procesji wokół kościoła, a bohaterami są Polacy, określeni leksemami Lachy, oraz Mazur. Nazwanie oddzielnie Lachów i Mazura wskazuje na tradycyjne rozróżnienie polskich osadników pochodzenia szlacheckiego i chłopskiego. Opis działania bohaterów sugeruje, iż traktowali oni obrzęd rutynowo, bez głębszej refleksji. Według autora przedstawiciele „Lachów” chwycili jakieś „przypadkowe przedmioty” i zaczęli chodzić wokół kościoła. Mazur postanowił wziąć z nich przykład, wedle autora - „z powodu swej nabożności” (ibid.: 178). Może to być ironiczna aluzja do faktu, iż szlachecka kultura była uważana za „lepszą”. Mazur dołączył zatem do procesji, niosąc przypadkowo podniesioną kamienną figurę. Czynność okazała się szczególnie męcząca, bohater modlił się o szybkie jej zakończenie, ale modlitwy były daremne. W końcu stracił cierpliwość i zrezygnował 
z dalszej „procesji” (ibid.). Utwór sugeruje zatem słomiany zapał oraz bezrefleksyjny stosunek do czynności religijnych bohatera.

Z kolei w utworze pt. Straszny sąd obserwujemy reakcję Mazura na kazanie o Sądzie Ostatecznym. Bohater zwraca się bezpośrednio do Jezusa z zarzutem, że ten będzie samotny w raju, jeśli będzie tak surowo sądził. Leksem Jezus i forma adresatywna Jezu zostały zapisane alfabetem łacińskim, co podkreśla przynależność bohatera do określonego kręgu kulturowego (ibid.: 175).

Powierzchowny stosunek do religii ukazuje też utwór pt. Nabożny ksiądz, którego sam tytuł ma charakter ironiczny. Tekst opiera się na dialogu Mazura z biskupem. Ten pierwszy daje szczerą charakterystykę miejscowego księdza, nie pomijając żadnych gorszących szczegółów. Nie widzi nic złego w fakcie, iż lokalni katoliccy duchowni mają dzieci i chrzczą je sobie nawzajem, a ponadto chwali swego księdza za to, że ten, mimo stanu nietrzeźwości, А все-таки цілу мшу // Слічно відправляє (całą mszę odprawia ślicznie) (ibid.: 179). $Z$ dialogu wynika, że rozmówcy różnie oceniają to samo postępowanie. Mamy zatem ponownie odmienne rozumienie $z \nmid e-$ go uczynku, tworzące efekt komiczny. Odmienny obraz świata bohaterów może też implikować sama strategia językowa autora: zestawia on ze sobą dwa języki - poprawną polszczyznę duchownego, zapisaną alfabetem łacińskim, i ukraińskie repliki Mazura.

Sam motyw zetknięcia różnych kultur i języków, problem braku wspólnego kodu na poziomie językowym, implikujący brak porozumienia w sferze światopoglądowej, ma swe źródła w ojczystym folklorze autora, np. w podolskich i galicyjskich anegdotach. Ich oś tematyczną stanowi często powierzchowna znajomość własnych zwyczajów obrzędowo-religijnych i kulturowych (Vremennik': 128; Hnatyuk 1899: 174-184, 1904: 136-137)

Postać Mazura wchodzi też w relację z innym reprezentowanym $\mathrm{w}$ „spiwomowkach" stereotypowym typem - postacią Lacha pana. Obaj przynależą do tego samego kręgu wyznaniowego, posługują się językiem polskim, jednak na ich obraz tekstowy składają się odmienne cechy. O zróżnicowaniu społecznym obu postaci można pośrednio wnioskować na podstawie ukazanych przez Rudanskiego cech Lacha, nieobecnych w obrazie Mazura, jak: buta, zarozumialstwo, skłonność do przechwałek, pogardliwy stosunek do chłopstwa (np. Rudans'kyy 1988: 102-104, 169-170, 175-176, 248-249).

Rudanski, czerpiąc z lokalnych realiów kulturowo-językowych, twórczo rozwinął wątki obecne w folklorze ukraińskim, łącząc motywy odmienności językowej z satyrą obyczajową. Wielojęzyczność implikuje zatem rozważania o odmienności

7 O powierzchownym stosunku do religii ze strony galicyjskich Mazurów pisał również dziewiętnastowieczny rosyjski etnograf i podróżnik Wasilij I. Kielsijew. Zwracał on również uwagę na widoczny brak wspólnej identyfikacji narodowej pomiędzy Mazurami a „Lachami” (por. Kel'siyev 1868). 
światopoglądowej i ukazuje absurdalność sytuacji wynikających z braku porozumienia bohaterów na różnych poziomach. Mazur rozmawia z przedstawicielami odmiennych stanów społecznych, grup etnicznych, a także zwraca się do sił nadprzyrodzonych. Wszyscy oni okazują się „obcymi” - „głuchymi” na jego słowa. Język w utworach Rudanskiego jest swoistym „zwierciadłem duszy” bohaterów. Brak wspólnego kodu komunikacyjnego bądź odmienna konceptualizacja dobrych czy złych czynów - wskazują na zróżnicowanie światopoglądu ludowego poszczególnych postaci reprezentowanych w omawianych utworach.

\section{Literatura}

Andrusieczko P., 1999, Postać Kozaka w folklorze i obyczaju polskim, [w:] G. Kotarski, M. Figura (red.), Oblicza Wschodu w kulturze polskiej, „Poznańskie Studia Wschodoznawcze", Poznań, s. 369-377.

BARTMí́ski J., 1999, Punkt widzenia, perspektywa, jezykowy obraz świata, [w:] idem (red.), Jezykowy obraz świata, wyd. 2 popr., Lublin, s. 103-120.

Bartmiński J., 2010, Pojęcie językowego obrazu świata i sposoby jego operacjonalizacji, [w:] P. Czapliński, A. Legeżyńska, M. Telicki (red.), Jaka antropologia literatury jest dzisiaj możliwa?, Poznań, s. 155-178.

Bartmiński J., Niebrzegowska S., 1998, Profile a podmiotowa interpretacja świata, [w:] J. Bartmiński, R. Tokarski (red.), Profilowanie w języku i w tekście, Lublin, s. 211-224.

Berezovich E.L., Кuchкo V.S., 2017, Once More on the Etymology of the Russian Word Mazurik 'Cheater' (in Light of the Cultural and Linguistic Image of Mazur in Slavic Traditions), „Slověne” 6, $\mathrm{nr}$ 1, s. 413-448.

Bobrzý́ski M., 1879, Dzieje Polski w zarysie, Warszawa - Kraków.

Borowska M., 2005, Kosmologia poety i podróżnika. Jezzkowy i tekstowy obraz stońca, gwiazd i księżyca w poezji Josifa Brodskiego, „Przekładaniec” nr 30: Brodski, s. 95-110.

Bystroń J.S., 1995, Megalomania narodowa, Warszawa.

Chubinskiy P.P., 1878, Trudy Etnografichesko-statisticheskoy ekspeditsii v Zapadno-Russkii kray snaryazhennoy Imperatorskim Russkim geograficheskim obshchestvom (Yugo-Zapadnyy otdyel): materialy i izsledovaniya, t. 2, Peterburg.

Dobrzycki S., 1900, O tak zwanem mazurowaniu w języku polskim, Kraków.

DzIĘGIEl E., 2010, Polska gwara wsi Zielonej na Podolu na tle innych gwar południowokresowych. Fleksja imienna i werbalna, Kraków.

DzIĘGIEL E., 2013, O losach etnonimów „Lach” i „Mazur” na dawnych Kresach południowo-wschodnich, [w:] eadem, T. Korpysz (red.), Niejedno ma imię... Prace onomastyczne i dialektologiczne dedykowane Profesor Ewie Wolnicz-Pawłowskiej, Warszawa, s. 117-132.

Franko I., 2010, Dodatkovi tomy do zibrannya tvoriv u 50-y tomakh, t. 54, Kyyiv.

Gieysztor A., Samsonowicz H., 1994, Dzieje Mazowsza do 1526 roku, Warszawa.

GoeHring C., 1867, Historya narodu polskiego od jego początku aż do teraźniejszości, t. II, Lwów.

Herasymenko V., 1925, Novi materiyaly do biohrafiyi S.V. Rudans'koho, „Zapysky Istorychno-filolohichnoho viddilu VUAN", z. V, s. 20-31.

Herasymenko V.Y., (red.), 1956, Stepan Rudans'kyy. Tvory, Kyyiv. 
HNATyuk V., 1899, Etnografichnyy zbirnyk, t. VI: Halyts'ko-rus'ki anektody, L'viv.

HNatyuk V., 1904, Etnografichnyy zbirnyk, t. XV: Znadoby do halyts'ko-rus'koyi demonologiyi, L'viv.

IoANidi A.L., Bondarenko A.I. (red.), 1984, Narod pro relihiyu. Ukrayins'ka narodna antyrelihiyna tvorchist' (vydannya druhe, pereroblene i dopovnene), Kyyiv.

JabŁonowski A., 1910, Pisma, t. II: Kresy ukrainne, Warszawa.

KADULSKA I., 1982, Formy intermediów sceny szkolnej połowy XVIII wieku, [w:] Z. Goliński, J. Maciejewski, T. Ulewicz (red.), Miscellanea z doby Oświecenia, „Archiwum Literackie”, t. XXV, Wrocław - Warszawa - Kraków - Gdańsk - Łódź, s. 7-33.

Кајтосн W., 2008, Językowe obrazy świata i człowieka $w$ prasie młodzieżowej i alternatywnej, t. 1, Kraków.

Kel'siyev V.I., 1868, Galichina i Moldaviya. Putevyye pis'ma, S.-Peterburg.

Kieffer-Kostanecka M., 1969, Nazwy „Mazowsze” $i$ „Płock” w świetle nauki współczesnej, „Notatki Płockie” nr 4 (53), s. 23-25.

Kireyevskiy P.V., 1864, Pesni, sobrannyye P.V. Kireyevskim izdany Obshchestvom lyubiteley rossiyskoy slovesnosti, t. 6, Moskva.

Kolberg O., 1963, Dzieła wszystkie, t. 26: Mazowsze, cz. 3, Wrocław - Kraków - Warszawa.

Kosmeda T., 2015, Stepan Rudans'kyj. Fenomen egocentryzmu zapozyczen' u poetycznomu dyskursi, [on-line:] https://md-eksperiment.org/post/20181129-fenomen-egocentrizmu.

Kosmeda T., 2016, Stepan Rudans'kyy - mayster zhanru spivomovky: rozbudova ihrovoyi stylistyky ukrayins'koyi movy, „Studia Ukrainica Posnaniensia” z. 4, s. 55-67.

KozŁowski F.A., 1858, Dzieje Mazowsza za panowania książat, Warszawa.

Kryms'кy A., Levchenko M., 1926, Znadoby dlya zhyttyepysu Stepana Rudans'koho (18331873), Kyyiv.

Kurochkin O., 2011, Personazhi „inshykh” v ukrayins'komu vertepi, „Naukovi zapysky Natsional'noho universytetu »Ostroz'ka akademiya«. Seriya Kul'turolohiya” nr 8, s. $100-108$.

LewIn P., 1961, Problematyka społeczna intermedium polskiego z XVI-XVII w., „Pamiętnik Literacki” LII, s. 1-37.

MaćKiewiCZ J., 1999, Co to jest „językowy obraz świata”, „Etnoligwistyka” 11, s. 7-24.

Malec M., 2002, Słownik etymologiczny nazw geograficznych Polski, Warszawa.

Michalczuk K., Czubiński P., 2006, Polacy w Regionie Południowo-Zachodnim [wybór], [w:] J. Rieger (red.), Język polski dawnych Kresów Wschodnich, t. 3, Warszawa, s. 201-251.

Myshanych S.V., 2003, Fol'klorystychni ta literaturoznavchi pratsi, t. 2, Donets'k.

Niewiara A., 2010, Polskie stereotypy narodowe w świetle badań diachronicznych, „LingVaria" nr 2 (10), s. 171-183.

Nomys M. (red.), 1864, Ukrayins'ki prykazky, prysliv'ya y take ynshe. Zbirnyky O.V. Markovycha y druhykh, S.-Peterburh.

Novak V.S., 2011, Vyasyel'naya tradytsyya Homyel'shchyny (fal'klorna-etnahrafichny zbornik), Minsk.

Окои́ J., 1986, Intermedium polskie XVII wieku. Próba typologii, „Pamiętnik Literacki” LXXVII, s. 101-138.

ОтамаNovs'кy V., 1929, Do pytannya pro rid poeta Stepana Rudans'koho, „Zapysky Istorychno-filolohichnoho viddilu VUAN" z. 25, s. 119-123.

PAjDzińska A., 2001, My, to znaczy... (z badań językowego obrazu świata), „Teksty Drugie” nr 1, s. 33-54. 
Piddubna N.V., 2014, Movnyy obraz svyashchennosluzhytelya v „Spivomovkakh” Stepana Rudans'koho (do 18orichchya vid dnya narodzhennya pys'mennyka), „Linhvistychni doslidzhennya" nr 38, s. 160-168.

Pielużek M., 2015, Ideologiczne obrazy świata w mediach alternatywnych - nacjonalistów i anarchistów, „Zeszyty Prasoznawcze” 58, nr 4 (224), s. 795-828.

PoŁujański A., 1859, Wędrówki po gubernji augustowskiéj w celu naukowym odbyte, Warszawa.

Putilov B.N., Dobrovol'skiy B.M., 1960, Istoricheskiye pesni XIII-XVI vekov, Leningrad.

RADzIK R., 1997, Palyaki - Byelarusy: uzayemnyya stereatypy w XIX i XX st.(da 1939 h.), „Byelaruski histarychny ahlyad”, t. 4, z. 1-2 (6-7), [on-line:] http://www.data.minsk.by/ bhr/bel/6-7/67_3.html.

RudAns'Kyy S., 1988, Spivomovky. Pisni, prykazky, dytyachi prykazky, red. M. Honcharuk, Kyyiv.

SemenoH O., 2004, Ukrayins'kyy fol'klor, Hlukhiv.

SGKP: B. Chlebowski (red.), Słownik geograficzny Królestwa Polskiego i innych krajów słowiańskich, t. XIII, Warszawa 1893.

SILETS'KYY Y., 2009, Stereotypy „lyakha” ta „moskalya” u tradytsiynomu svitohlyadi ukrayintsiv: spil'ni ta vidminni rysy, [w:] L. Zashkil'nyak (red.), Istorychni mify i stereotypy ta mizhnatsional'ni vidnosyny v Suchasniy Ukrayini, L'viv, s. 123-130.

SMOLEŃsKi W., 1908, Szkice z dziejów szlachty mazowieckiej, Kraków.

SW: J. Karłowicz, A.A. Kryński, W. Niedźwiedzki (red.), Słownik języka polskiego, t. I-VIII, Warszawa 1900-1927.

SWIL: A. Zdanowicz, M. Bohusz Szyszko, J. Filipowicz, W. Tomaszewicz, F. Czepieliński, W. Korotyński, z udziałem B. Trentowskiego, Słownik języka polskiego, t. I-II, Wilno 1861.

Szujski J., 1864, Dzieje Polski podług ostatnich badań, t. 3, Lwów.

TokARski R., 2016, Od językowego obrazu świata do obrazów świata w języku, „Język Polski” XCVI, s. 28-37.

Tyrpa A., 2006, Losy etnonimu Mazur, [w:] J. Duma (red.), Onomastyka regionalna, Olsztyn, S. 181-193.

VREMENNIK': Vremennik' Instituta stavropigiyskogo s' m'syatseslovom' na god' prostyy 1870 , L'vov 1870.

Wojciechowski T., 1873, Chrobaccya: Rozbior starozytnosci slowianskich, t. 1, Kraków.

Wolanowski I., 1896, Szopki i „Herody” w Lubelskiem, „Wisła” X, z. 3, s. 479-480.

Yermolenko S., 2009, Movno-estetychni znaky ukrayins'koyi kul'tury u tvorakh Stepana Rudans'koho, [w:] V.S. Kalashnyk, Y.M. Bezkhmuryy, L.I. Kolomiyets'ta (red.), U vymirakh slova: zbirnyk naukovykh prats' (do yuvileyu prof. kafedry ukrayins'koyi movy L.H. Savchenko), Kharkiv, s. 15-21.

ZемS'Kу Y.S., 2015, Lyudyna u leshchatakh svoyeyi epokhy: Stepan Rudans'kyy, vyprobuvannya doli, „Osvita, nauka i kul'tura na Podilli”, t. 22, Kam'yanets'-Podil's'kyy, s. 392-402.

Żuk G., 2010, Językowy obraz świata w polskiej lingwistyce przełomu wieków, [w:] M. Karwatowska, A. Siwiec (red.), Przeobrażenia w języku i komunikacji medialnej na przełomie XX i XXI wieku, Chełm, s. 239-257. 


\section{Linguistic and Textual Image of Mazur in Poetry by Stepan Rudans'kyy Summary}

The main issue discussed in this article is the linguistic and textual image of Mazur in the poetry by Stepan Rudans'kyy. Rudans'kyy invented his own poetic form called "spivomovka", which was inspired by Ukrainian folklore. Those humorous poems mainly focused on describing local types of Podolia ethnic groups, such as Cossacks, Ruthenians, Russians (Moskal), rabbis, Polish colonists ( $M a-$ zur-[Mazovian], Lach). The creation of Mazur in poems by Rudans'kyy was largely influenced by the image of Mazur in the Ukrainian and Polish folklore. The linguistic and textual images of the character are created by Mazur's replies, as well as descriptions of his activity. Mazur is characterized by the following features: sincerity, simplicity, naivety, superficial religiousness and cheerfulness. Through presenting the characteristics of Mazur, the author also draws our attention to the important issue of the lack of code that would be common to the interlocutors, both in terms of linguistics and culture. 